\title{
Checklist of the fishes from Jamari River basin, in areas under influence of dams, Rondônia, Brazil
}

\author{
Rianne Caroline de Oliveira ${ }^{1,2} \mathbb{D}^{-}$, Gabriel de Carvalho Depráa ${ }^{1,2}$, Cláudio Henrique Zawadzki ${ }^{1,2,3}$, João Carlos \\ Barbosa da Silva \& Weferson Júnio da Graça ${ }^{1,2,3}$ \\ ${ }^{1}$ Universidade Estadual de Maringá, Núcleo de Pesquisas em Limnologia, Ictiologia e Aquicultura, Av. \\ Colombo, 5790, CEP 87020-900, Maringá, PR, Brasil \\ ${ }^{2}$ Universidade Estadual de Maringá, Programa de Pós-Graduação em Ecologia de Ambientes Aquáticos \\ Continentais, Av. Colombo, 5790, CEP 87020-900, Maringá, PR, Brasil \\ ${ }^{3}$ Universidade Estadual de Maringá, Centro de Ciências Biológicas, Departamento de Biologia e Núcleo de \\ Pesquisas em Limnologia, Ictiologia e Aquicultura, Av. Colombo, 5790, CEP 87020-900, Maringá, PR, Brasil \\ ${ }^{4}$ Biologic Consultoria Ambiental, Av. Alziro Zarur, 1367, CEP 87075-010, Maringá, PR, Brasil \\ *Corresponding author: Rianne Caroline de Oliveira, e-mail: rianne.oliveira@gmail.com
}

OLIVEIRA, R. C., DEPRÁ, G. C., ZAWADZKI, C. H., SILVA, J. C. B., GRAÇA, W. J. Checklist of the fishes from Jamari River basin, in areas under influence of dams, Rondônia, Brazil. Biota Neotropica. 20(1): e20190803. http://dx.doi.org/10.1590/1676-0611-BN-2019-0803

\begin{abstract}
The Madeira River is the most extensive tributary of the Amazon River and has the largest diversity of fishes in the world. On its right bank, the Madeira River receives the Jamari River, in which the first hydroelectric power plant (HPP) in State of Rondônia, Samuel HPP, was built. Besides this, other dams were built in the Jamari River and its tributaries, however, the available information in the scientific literature about the ichthyofaunistic diversity of this basin is rare. This work aims to provide an ichthyofaunistic inventory in a region of the Jamari river basin, in the State of Rondônia, where three small hydropower plants (SHPs) were implemented. The ichthyofauna was sampled in 16 expeditions between August 2015 and December 2018. Gill nets and seine nets were used with different meshes, as well as longlines and cast nets at different times of the day. Additionally, 81 INPA lots of species from the Samuel HPP area of influence were reanalyzed. Fish were identified according to the specialized literature, as well as in consultations with experts of various taxonomic groups. Voucher specimens of the species were cataloged and deposited in the ichthyological collection of the Núcleo de Pesquisas em Limnologia, Ictiologia e Aquicultura (Nupélia) of the Universidade Estadual de Maringá. A total of 230 species were recorded, of which 22 were putative new species, 117 were added to the Jamari River basin and 28 to the Madeira River basin. The continuation of the studies in this section of the Jamari river basin is fundamental for analysis of local impact due to the presence of dams. Moreover, the addition of putative new species to the Madeira River basin indicates gaps in the knowledge of Neotropical ichthyofauna. Keywords: Diversity, species list, Madeira River, Amazon basin, freshwater fish.
\end{abstract}

\section{Lista das espécies de peixes da bacia do rio Jamari, em áreas sob influência de reservatórios, Rondônia, Brasil}

Resumo: O rio Madeira é o mais extenso afluente do rio Amazonas e possui a maior biodiversidade de peixes do mundo. Em sua margem direita, o rio Madeira recebe o rio Jamari, no qual foi construída a primeira usina hidrelétrica (UHE) do estado de Rondônia, a UHE Samuel. Além desta, outros barramentos foram construídos no rio Jamari e em seus afluentes, contudo são raras as informações disponíveis na literatura científica sobre a diversidade ictiofaunística desta bacia. O objetivo deste trabalho foi providenciar um inventário ictiofaunístico na região da bacia do rio Jamari, no estado de Rondônia, onde foram implantadas três pequenas centrais hidrelétricas (PCHs). A ictiofauna foi amostrada em 16 expedições entre os meses de agosto de 2015 e dezembro de 2018. Foram utilizadas redes de espera e arrasto com malhas de diversos tamanhos, além de espinhéis e tarrafas em diferentes períodos do dia. Adicionalmente, 81 lotes de espécies do INPA da área de influência da UHE Samuel foram reanalisados. Os peixes foram identificados de acordo com a literatura especializada, bem como em consultas com especialistas de diversos grupos taxonômicos. Exemplares testemunho das espécies foram catalogados e depositados na coleção ictiológica do Núcleo de Pesquisas em Limnologia, Ictiologia e Aquicultura da Universidade Estadual de Maringá. Foram registradas 230 espécies, destas, 22 são possíveis espécies novas, 117 são acrescentadas à bacia do rio Jamari e 28 à bacia do rio Madeira. A continuação dos estudos neste trecho da bacia do rio Jamari é fundamental para análises de impacto local devido à presença de barramentos. Além disso, a adição de possíveis novas espécies à bacia do rio Madeira aponta lacunas no conhecimento da ictiofauna Neotropical. Palavras-chave: Diversidade, lista de espécies, rio Madeira, bacia Amazônica, peixe de água doce. 


\section{Introduction}

The Amazon basin is recognized for its high number of fish species, and the rate of endemism reaches large values, representing almost half of the recorded species (Reis et al. 2016). This ecosystem is mainly affected by the pollution from the use of mercury by mining, construction of dams, deforestation and overexploitation of several natural resources (Castello et al. 2013). Amazonian rivers have a lowly exploited hydroelectric potential in comparison to other Neotropical basins (Lima et al. 2017). Meanwhile, in this region, some 175 large hydroelectric plants are already in operation or under construction and 277 are planned for the coming years (Castello \& Macedo 2016).

Among the tributaries of the Amazon River, the Madeira River is the most extensive and one of the main rivers in South America, draining an area of approximately $984,000 \mathrm{~km}^{2}$ (Fearnside 2014). Its biodiversity is one of the largest in the world and recent studies have reported the existence of approximately 1,000 fish species (Ohara et al. 2015), of a total of 3,000 species estimated for the entire Amazon basin (Queiroz et al. 2013a).

The Jamari River is one of the main tributaries of the Madeira River, draining approximately $29,067 \mathrm{~km}^{2}$ (IBGE 2018). It is economically important for the State of Rondônia, especially since it was dammed to install the Samuel Hydroelectric Power Plant (HPP) in 1989, the first of the state (IBGE 2018). The single available inventory of the Jamari river ichthyofauna, reporting 122 species, focused the area around the Samuel dam, and was included in a study of the impacts caused by the power plant (Santos 1996).

Species richness estimates in Brazilian freshwater ecosystems are scarce and imprecise. Few basins have been inventoried, due to the lack of funding and poor gathering infrastructure (Agostinho et al. 2005). Inventories are important for recording species distributions, discovering new species, and comparing changes in richness and abundance over time due to environmental changes (Baird 2010).

Because (1) there is only data from an environmental impact study of Samuel HPP (Santos 1996); (2) the knowledge of ichthyofauna is limited to the studies carried out for the three other small hydropower plants (SHPs), so it is gray literature and it is not easily accessible; we do not know the approximate data of richness of fish species in the area. Thus, this study aimed to provide an ichthyofaunistic inventory of Jamari River basin, Rondônia, Brazil. In order to do this, we used collection data from fishes sampled around Samuel HPP and other three SHPs currently installed.

\section{Material and Methods}

\section{Study area}

The Jamari River is $563 \mathrm{~km}$ long and drains an area of $29,067 \mathrm{~km}^{2}$. It is one of the eight sub-basins of the Madeira River. Its headwaters are near of Campo Novo de Rondônia town, northwest of Serra dos Pacaás Novos, and flows into the right bank of the Madeira River in the State of Rondônia (IBGE 2018). Its main right-bank tributaries are Branco, Preto do Crespo, Canaã and Quatro Cachoeiras Rivers, and the left-bank ones are Maçangana and Candeias Rivers. The ichthyofauna was sampled in the Jamari River basin, in the area occupied by the Canaã, Santa Cruz de Monte Negro and Jamari SHPs, all in the State of Rondônia (Figure 1, Table 1).
The Canaã SHP is located in the Canaã River, near the municipality of Ariquemes. The Canaã River presents upstream preserved riparian vegetation, with low flow velocity and shallow depth. The other SHPs were installed in the main course of Jamari River. The Santa Cruz de Monte Negro SHP is located near the municipality of Monte Negro. Its upstream section presents preserved riparian vegetation, low hydrometric level (average 1 meter) and, in narrower areas, waterfalls with formation of waterholes are observed. The Jamari SHP is located downstream of the Santa Cruz de Monte Negro SHP. Its upstream section presents low water level (average $1 \mathrm{~m}$ ), moderate flow, numerous rock outcrops and punctual rapids. Downstream, the Jamari River is wider (mean of $35 \mathrm{~m}$ ), it has a strong flow, but with backwater areas.

\section{Sampling}

The specimens were collected with authorizations $01 / 2015$, $02 / 2015$ and $03 / 2015$ sent by the Secretaria de Estado do Desenvolvimento Ambiental (SEDAM) provided to JCBS. A total of 16 expeditions were carried out between August 2015 and December 2018 with the use of four different capture devices. Gillnets $(2.4 ; 3$; $4 ; 5 ; 6 ; 7 ; 8 ; 10 ; 12 ; 14$ and $16 \mathrm{~cm}$ between opposite knots) were operated in the marginal region and remained exposed from $16 \mathrm{~h}$ to $8 \mathrm{~h}$ on the following day, with a search at $22 \mathrm{~h}$. At the reservoir areas, gill nets were installed simultaneously in the marginal region, in the sub-surface of the open areas (pelagic region; surface) and deep areas (bathypelagic region; modified from Smith \& Petrere Junior, 2008).

Seine nets ( $10 \mathrm{~m}$ in length and $0.5 \mathrm{~cm}$ mesh) were operated once per turn at the littoral zone, during the nocturnal and diurnal period. Longlines ( 20 hooks, 10 units of $4 / 0$ interposed by 10 units of $7 / 0$ ) were operated in all environments. Hooks were baited at sunset and searched at night and in the morning of the following day. Cast nets (2.4, 4 and $6 \mathrm{~cm}$ between opposite knots) were operated in the lotic environments, each sample including five throws, with sampling at nocturnal and diurnal periods.

\section{Fish identification}

The captured fish were anesthetized in clove oil, fixed in formalin and sent to the Biologic Consultoria Ambiental laboratory. Subsequently, they were kept in $70 \%$ alcohol solution and sent for identification in the laboratory of the ichthyology collection of the Núcleo de Pesquisas em Limnologia, Ictiologia e Aquicultura (Nupélia) of the Universidade Estadual de Maringá. The classification by family and higher taxonomic levels followed Betancur-R et al. (2017) for bony fishes and McEachran \& Aschliman (2004) for Myliobatiformes. The classification of Characiformes followed Betancur-R et al. (2019). The classification of Loricariidae followed Lujan et al. (2015). The identification of the species was based on specialized papers (species descriptions, taxonomic revisions, etc.), on the keys present in Queiroz et al. (2013a), as well as on consultation with specialists in each taxonomic group. Individuals of the putative new species were photographed (Figure 3). Vouchers were deposited in the ichthyology collection of the Nupélia and they are available at http://splink.cria.org.br/. Uncatalogued specimens were in poor condition.

Because there are several differences between the list of the species sampled by us and that of Santos (1996), we decided to reanalyze lots collected by him and deposited at the Instituto Nacional de Pesquisas da Amazônia (INPA) collection. This reanalysis had two goals: (1) find 


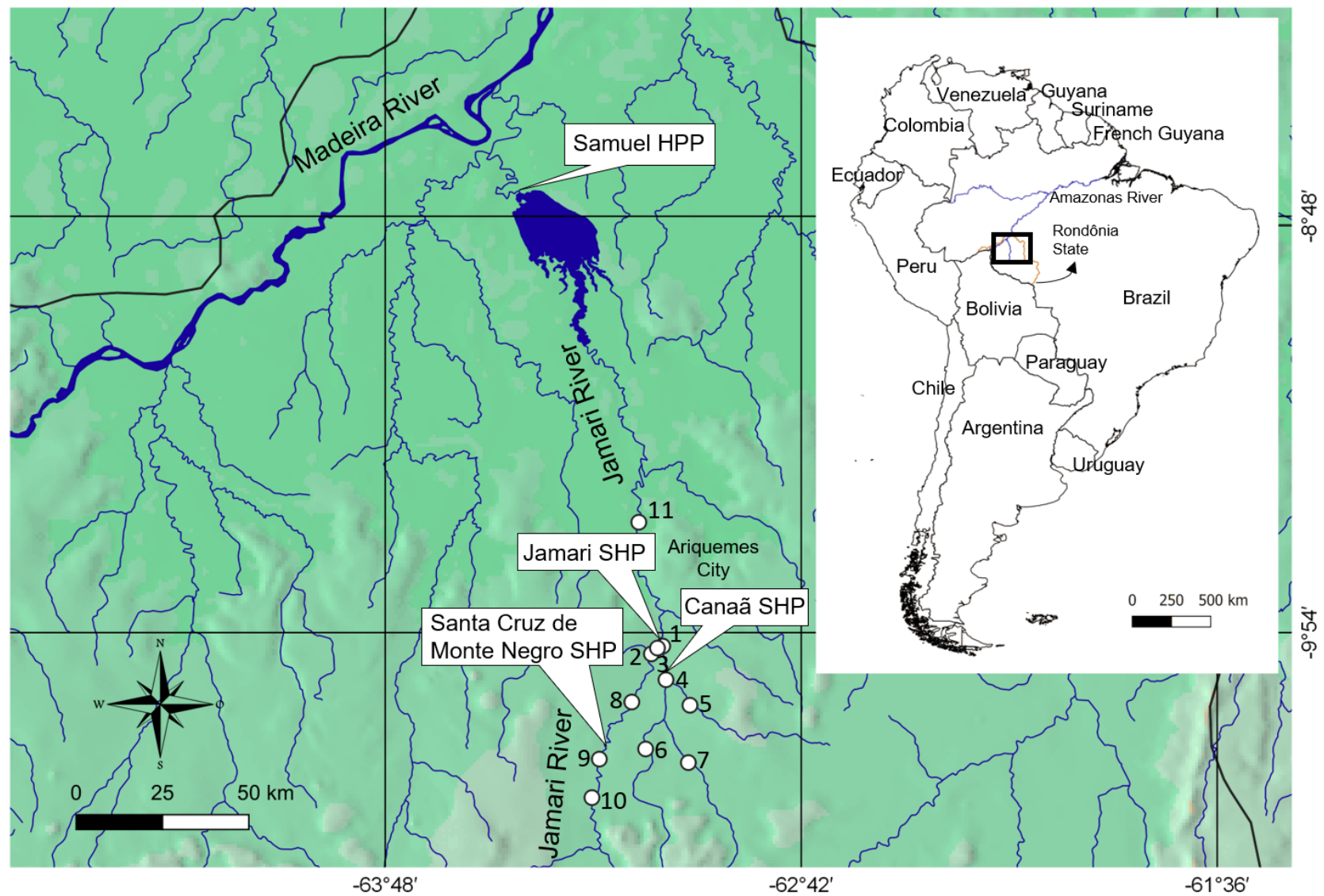

Figure 1. Sampling stations in the Jamari River: Canaã, Jamari and Santa Cruz de Monte Negro SHPs, with their approximate geographical coordinates: 1 Downstream of Jamari and Canaã SHPs; 2 - Itapoana River; 3 - Jamari SHP reservoir; 4 - Canaã SHP reservoir; 5 - Quatro Cachoeiras River; 6 - Upstream of the Canaã SHP; 7 - Pardo River; 8 - Downstream of Santa Cruz de Monte Negro SHP and Upstream of Jamari SHP; 9 - Santa Cruz de Monte Negro SHP reservoir; 10 - Upstream of Santa Cruz de Monte Negro SHP; 11 - Downstream of Jamari SHP.

species from the Jamari River which were not collected by us, in order to increase the number of species included in our list; (2) verify the taxonomic identity of the specimens collected by Geraldo Santos and included in Santos (1996), given that many species have been described or revised since 1996. Whenever we felt certain that a given species in our list could not have been presented in the list by Santos (1996) under a misidentified name, we considered it to be a new record for the Jamari River basin, unless the species has been recorded in a revisionary study or species description.

Queiroz et al. (2013a) did not record for the Madeira River basin some of the species recorded herein in the Jamari River basin. This is partially explained by the presence of putatively new species so far known only from the Jamari River basin, although some of the possible new species listed herein are probably more widespread in the Madeira River basin. Other species, which are already described, have been reported from the Madeira River basin in other papers, dealing with taxonomic revisions or species descriptions: Leporinus bleheri Géry (1999), Petulanos intermedius (Winterbottom 1980) (see Sidlauskas \& Santos 2005), Myloplus zorroi Andrade, Jégu \& Giarrizzo (2016), Mylossoma albiscopum (Cope 1872) (see Mateussi et al. 2018), Charax pauciradiatus (Günther 1864) (see Menezes \& Lucena 2014), Leporacanthicus galaxias Isbrücker \& Nijssen (1989),
Pimelodus albofasciatus Mees 1974 (see Santos 1996), Satanoperca curupira Ota, Kullander, Deprá, da Graça \& Pavanelli (2018). All of the species above have been reported in Brazilian territory, except $L$. bleheri, which was sampled in the Verde River, on the border between Brazil and Bolivia.

Other species were identified in Queiroz et al. (2013a) with a different name: Leporinus desmotes $=L$. jatuncochi (see Burns et al. 2017), L. cylindriformes $=$ L. niceforoi (this paper), Moenkhausia sp. "virgulata" = Astyanax guaporensis (see Marinho \& Ohara 2013), Moenkhausia sp. "collettii alta" = Astyanax guianensis (see Marinho et al. 2015), Moenkhausia cf. megalops $=$ M. abyss Oliveira \& Marinho (2016), Moenkhausia sp. "lepidura longa" = M. hasemani (see Marinho \& Langeani 2016), Ancistrus sp. 2 "Sotério" = Ancistrus cf. dolichopterus (this paper), Acistrus sp. 1 "Baixinho" = Ancistrus sp. (this paper), Hemiancistrus sp. "Bamburro" = Peckoltia cf. ephippiata Armbruster, Werneke \& Tan (2015), Pterygoplichthys pardalis $=P$. disjunctivus Weber (1991), Hemidoras morrisi = Opsodoras morrisi (see DoNascimiento et al. 2017), Opsodoras ternetzi $=$ Tenellus ternetzi (see Birindelli 2014), Rhamdia quelen = Rhamdia sp. (this paper), Hypophthalmus edentatus $=$ Hypophthalmus oremaculatus (see Littmann et al. 2015), "Pseudopimelodus" pulcher = Rhyacoglanis $\mathrm{sp}$. (see Shibatta \& Vari 2017). 
Table 1. Location of sampling stations in the Jamari River during the expeditions between August 2015 and December 2018.

\begin{tabular}{|c|c|c|}
\hline Number & Sampling stations & $\begin{array}{l}\text { Geographic } \\
\text { coordinates }\end{array}$ \\
\hline 1 & $\begin{array}{l}\text { Downstream of Jamari and Canaã } \\
\text { SHPs }\end{array}$ & $\begin{array}{l}9^{\circ} 56^{\prime} 20.73^{\prime \prime} \mathrm{S} \\
63^{\circ} 4^{\prime} 8.10^{\prime \prime} \mathrm{W}\end{array}$ \\
\hline 2 & Itapoana River & $\begin{array}{l}9^{\circ} 57^{\prime} 22.83^{\prime \prime} \mathrm{S} \\
63^{\circ} 5^{\prime} 45.79^{\prime \prime} \mathrm{W}\end{array}$ \\
\hline 3 & Jamari SHP reservoir & $\begin{array}{l}9^{\circ} 56^{\prime} 27.63^{\prime \prime} \mathrm{S} \\
63^{\circ} 4^{\prime} 47.87^{\prime \prime} \mathrm{W}\end{array}$ \\
\hline 4 & Canaã SHP reservoir & $\begin{array}{l}10^{\circ} 1 ' 28.93^{\prime \prime} \mathrm{S} \\
63^{\circ} 3^{\prime} 26.96^{\prime \prime} \mathrm{W}\end{array}$ \\
\hline 5 & Quatro Cachoeiras River & $\begin{array}{l}10^{\circ} 14^{\prime} 37.06^{\prime \prime} \mathrm{S}, \\
62^{\circ} 59^{\prime} 53.70^{\prime \prime} \mathrm{W}\end{array}$ \\
\hline 6 & Upstream of the Canaã SHP & $\begin{array}{l}10^{\circ} 12^{\prime} 27.50^{\prime \prime} \mathrm{S} \\
63^{\circ} 6^{\prime} 40.57^{\prime \prime} \mathrm{W}\end{array}$ \\
\hline 7 & Pardo River & $\begin{array}{l}10^{\circ} 5^{\prime} 31.45^{\prime \prime} \mathrm{S} \\
62^{\circ} 59^{\prime} 38.49^{\prime \prime} \mathrm{W}\end{array}$ \\
\hline 8 & $\begin{array}{l}\text { Downstream of Santa Cruz de } \\
\text { Monte Negro SHP and Upstream of } \\
\text { Jamari SHP }\end{array}$ & $\begin{array}{l}10^{\circ} 5^{\prime} 0.56^{\prime \prime} \mathrm{S} \\
63^{\circ} 8^{\prime} 52.10^{\prime \prime} \mathrm{W}\end{array}$ \\
\hline 9 & $\begin{array}{l}\text { Santa Cruz de Monte Negro SHP } \\
\text { reservoir }\end{array}$ & $\begin{array}{l}10^{\circ} 14^{\prime} 3.79^{\prime \prime} \mathrm{S} \\
63^{\circ} 14^{\prime} 1.34^{\prime \prime} \mathrm{W}\end{array}$ \\
\hline 10 & $\begin{array}{l}\text { Upstream of Santa Cruz de Monte } \\
\text { Negro SHP }\end{array}$ & $\begin{array}{l}10^{\circ} 20^{\prime} 10.13^{\prime \prime} \mathrm{S}, \\
63^{\circ} 15^{\prime} 11.71^{\prime \prime} \mathrm{W}\end{array}$ \\
\hline 11 & Downstream of Jamari SHP & $\begin{array}{l}9^{\circ} 36^{\prime} 30.61^{\prime \prime} \mathrm{S} \\
63^{\circ} 7^{\prime} 45.49^{\prime \prime} \mathrm{W}\end{array}$ \\
\hline
\end{tabular}

\section{Results}

The 49,947 specimens captured and those belonging to the 81 INPA lots are distributed in 230 species belonging to 42 families and ten orders (Table 2). Just the 81 INPA lots reanalyzed by us yielded an additional 55 species (Table 2). A total of 117 species were added to the Jamari River basin and 28 species to the Madeira River basin (Table 2).

The richest order was Characiformes, with 18 families and 121 species $(52.6 \%)$, followed by Siluriformes with ten families and 63 species, (27.4\%) and Cichliformes with one family and 21 species (9.1\%) (Figure 2). Gymnotiformes presented five families with 14 species $(6.1 \%)$, Clupeiformes presented two families and four species (1.7\%) and Myliobatiformes presented one family and two species $(0.9 \%)$ (Figure 2). Synbranchiformes, Pleuronectiformes, Beloniformes, Tetraodontiformes presented just one species, $0.4 \%$ each. Sciaenidae, which is incertae sedis in Eupercaria, was represented by a single species too $(0.4 \%)$ (Figure 2$)$.

The richest family was Characidae with 45 species (19.6\%), followed by Cichlidae with 21 species (9.1\%) and Anostomidae with 20 species (8.7\%) (Figure 2). Loricariidae and Pimelodidae presented 14 species each (6.1\% each); Serrasalmidae 13 (5.7\%); Curimatidae and Doradidae 10 each $(4.3 \%$ each) (Figure 2$)$. The other families summed 83 species (total of 36.1\%) (Figure 2). Among the latter, 13 families (Parodontidae, Prochilodontidae, Chalceidae, Lebiasinidae, Aspredinidae, Cetopsidae, Hypopomidae, Engraulidae, Synbranchidae, Achiridae, Belonidae, Tetraodontidae and Sciaenidae) presented only one species (total of 5.7\%) (Figure 2).
Among captured and reexamined specimens, 22 putatively new species were found, representing approximately $9.6 \%$ of all species: Leporinus sp., Apareiodon sp., Astyanax sp., Hyphessobrycon sp., Moenkhausia sp., Thayeria sp. "hemiodus", Creagrutus sp., Gymnotus sp., Corydoras sp., Ancistrus sp., Hypostomus sp., Typhlobelus sp., Ceptosidium sp., Phenacorhamdia sp., Rhamdia sp., Megalonema sp., Pimelodus sp., Batrochoglanis sp. "aff. B. villosus", Rhyacoglanis sp., Synbranchus sp., Geophagus sp. 1 and Geophagus sp. 2 (Figure 3).

\section{Discussion}

Our study added 117 species to the 122 listed by Santos (1996) from the Jamari River basin, and 28 species to the 820 listed by Queiroz et al. (2013a) from the Madeira River basin in Brazilian territory. From those INPA lots reanalyzed, several species collected by Geraldo Santos were not included in Santos (1996), not even under a different name. However, we were not able to verify all the identifications by Santos (1996), once the author did not provide the catalog numbers of the lots analyzed by him, and we failed to find in the INPA collection several lots collected in the Jamari River basin. The record of 22 putatively new species and the scarce information on the threat status of most species recorded in the present study are examples of gaps still existing in the knowledge of Neotropical ichthyofauna.

The results followed the known patterns for Neotropical ichthyofauna (Lowe-McConnell 1999), showing the highest percentage of Characiformes species, followed by Siluriformes and Cichliformes. The same proportion at the order level was found for other sites in the Madeira River basin (Camargo \& Giarrizzo 2007, Perin et al. 2007, Casatti et al. 2013). Regarding families with greater species richness, our work presented greater richness in Characidae, followed by Cichlidae and Anostomidae. However, other authors obtained different relative amounts: Characidae $>$ Cichlidae $>$ Loricariidae (Camargo \& Giarrizzo 2007); Characidae $>$ Loricariidae $>$ Cichlidae (Casatti et al. 2013); Loricariidae $>$ Characidae $>$ Cichlidae (Perin et al. 2007); Curimatidae $>$ Characidae $>$ Loricariidae (Araújo et al. 2009). Although this difference suggests the high variability of species distribution in the different tributaries of the Madeira River basin, and probably a high percentage of species to be discovered (Casatti et al. 2013), those works were conducted in distinct environments (e.g. streams, Araújo et al. 2009, Casatti et al. 2013 and Perin et al. 2007; river, Camargo \& Giarizzo). Also, those studies employed different fishing gears, which tend to capture different species, as shown by Oliveira et al. (2014).

Jamari River has Samuel HPP, which was installed in 1989, and three other SHPs which were installed after 2015. We did not analyze the effects from those dams installed in the Jamari River basin, but literature shows that tropical rivers are the main targets for dam construction due to their high hydroelectric potential (ANA 2019), which also affects aquatic ecosystems (Fearnside 2014). In Brazil, the Amazon basin is already considered the final energy frontier, since the other basins of the country have their hydroelectric potential almost exhausted (Doria et al. 2018, ANEEL 2019). If, on the one hand, hydroelectric plants generate more energy, on the other they cause both environmental and socio-economic impacts. The most evident issue of dam construction is the habitat fragmentation with blocking of access between the spawning and initial development sites of the migratory species (Agostinho et al. 2002), which makes the development of new populations unfeasible. 
Table 2. List of fish species from areas altered by the Canaã, Santa Cruz de Monte Negro and Jamari SHPs, and by the Samuel HPP, all in the Jamari River basin, Rondônia, Brazil. The presence in each sampling site is represented by an "x". Species which are new records for the Jamari and/or Madeira river basins are indicated by an "*". Species we were not capable to notify if they are new records are indicated by "?". The threat categories for species are in accordance with the IUCN (2019) Red List (Data Deficient = DD; Least Concern = LC). Species which do not have information in the IUCN (2019) are indicated by "-". In the Madeira River column, "a" represents species which were reported from the Madeira River basin in other papers, but not in Queiroz et al. (2013a); "b" represents those species which have been identified in Queiroz et al. with a different name (see Material and Methods to more information). The numbers in the header represent the sample stations (see Figure 1). Characidium aff. zebra was collected in our work, but it was not deposited at NUP. References for classification are in Material and Methods.

\begin{tabular}{|c|c|c|c|c|c|c|c|c|c|c|c|c|c|c|c|}
\hline \multirow[b]{2}{*}{ Classification } & \multicolumn{11}{|c|}{ Sampling sites } & \multicolumn{2}{|c|}{ New records } & \multirow[t]{2}{*}{ IUCN } & \multirow[t]{2}{*}{ Voucher } \\
\hline & 1 & 2 & 3 & 4 & 5 & 6 & 7 & 8 & 9 & 10 & 11 & $\begin{array}{c}\text { Jamari } \\
\text { River }\end{array}$ & $\begin{array}{c}\text { Madeira } \\
\text { River }\end{array}$ & & \\
\hline
\end{tabular}

\section{CHONDRICHTHYES}

\section{MYLIOBATIFORMES}

\section{Potamotrygonidae}

Potamotrygon falkneri Castex \& Maciel 1963

Potamotrygon orbignyi (Castelnau 1855)

\section{OSTEICHTHYES}

\section{CLUPEIFORMES}

\section{Engraulidae}

Lycengraulis batesii (Günther 1868)

\section{Pristigasteridae}

Ilisha amazonica (Miranda Ribeiro 1920)

Pellona castelnaeana Valenciennes 1847

Pellona flavipinnis (Valenciennes 1837)

\section{CHARACIFORMES}

\section{Crenuchidae}

Characidiinae

Characidium aff. zebra Eigenmann 1909

Characidium etheostoma Cope 1872

\section{Erythrinidae}

Hoplerythrinus unitaeniatus (Spix \& Agassiz 1829)

Hoplias gr. malabaricus (Bloch 1794)

Anostomidae

Anostomoides atrianalis Pellegrin 1909

Gnathodolus bidens Myers 1927

Hypomasticus pachycheilus (Britski 1976)

Laemolyta proxima (Garman 1890)

Laemolyta taeniata (Kner 1858)

Leporellus vittatus (Kner 1858)

Leporinus bleheri Géry 1999

Leporinus brunneus Myers 1950

Leporinus fasciatus (Bloch 1794)

Leporinus friderici (Bloch 1794)

Leporinus jamesi Garman 1929

Leporinus jatuncochi Ovchynnyk 1971

Leporinus niceforoi Fowler 1943

Leporinus sp.

Megaleporinus trifasciatus (Steindachner 1876)

Petulanos intermedius (Winterbottom 1980)
$\mathrm{X}$
DD

LC NUP 19376
NUP 19827

$\begin{array}{lll}* & \text { LC } & \text { NUP } 19376\end{array}$

LC INPA 10401, INPA 12092

LC INPA 7451, INPA 16249

LC INPA 15154

LC INPA 7450
INPA 14143

NUP 19333

NUP 19389

NUP 19747

INPA 10621, INPA 15182, INPA 15185 , INPA 15193

INPA 48820

NUP2 1266 , INPA 1371

NUP 19352

$\begin{array}{lllllllllll}\mathrm{x} & \mathrm{x} & \mathrm{x} & \mathrm{x} & \mathrm{x} & \mathrm{x} & \mathrm{x} & \mathrm{x} & - & \text { NUP } 19352 \\ & & & & & & & & & & \end{array}$

$\begin{array}{rrrrr}\mathrm{x} & \mathrm{x} & & \\ \mathrm{x} & & * & \text { NUP } 19320\end{array}$

$\mathrm{X}$

a

NUP 19446

INPA 15403

INPA 15411

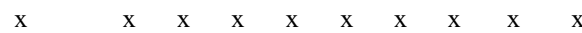

$\begin{array}{llllllllllll} & \mathrm{x} & \mathrm{x} & \mathrm{x} & \mathrm{x} & \mathrm{x} & \mathrm{x} & \mathrm{x} & \mathrm{x} & \mathrm{x} & \mathrm{x}\end{array}$ $\mathrm{x}$

$\begin{array}{lllllllllll}\mathrm{x} & \mathrm{x} & \mathrm{x} & \mathrm{x} & \mathrm{x} & \mathrm{x} & \mathrm{x} & \mathrm{x} & \mathrm{x} & \mathrm{x}\end{array}$

$\begin{array}{lllllllllllllll}x & x & x & x & x & x & x & x\end{array}$
NUP 19531

NUP 19353

INPA 52170

NUP 19381

NUP 19375

NUP 19345

NUP 19745 
Oliveira, R.C. et al

Continuation Table 2.

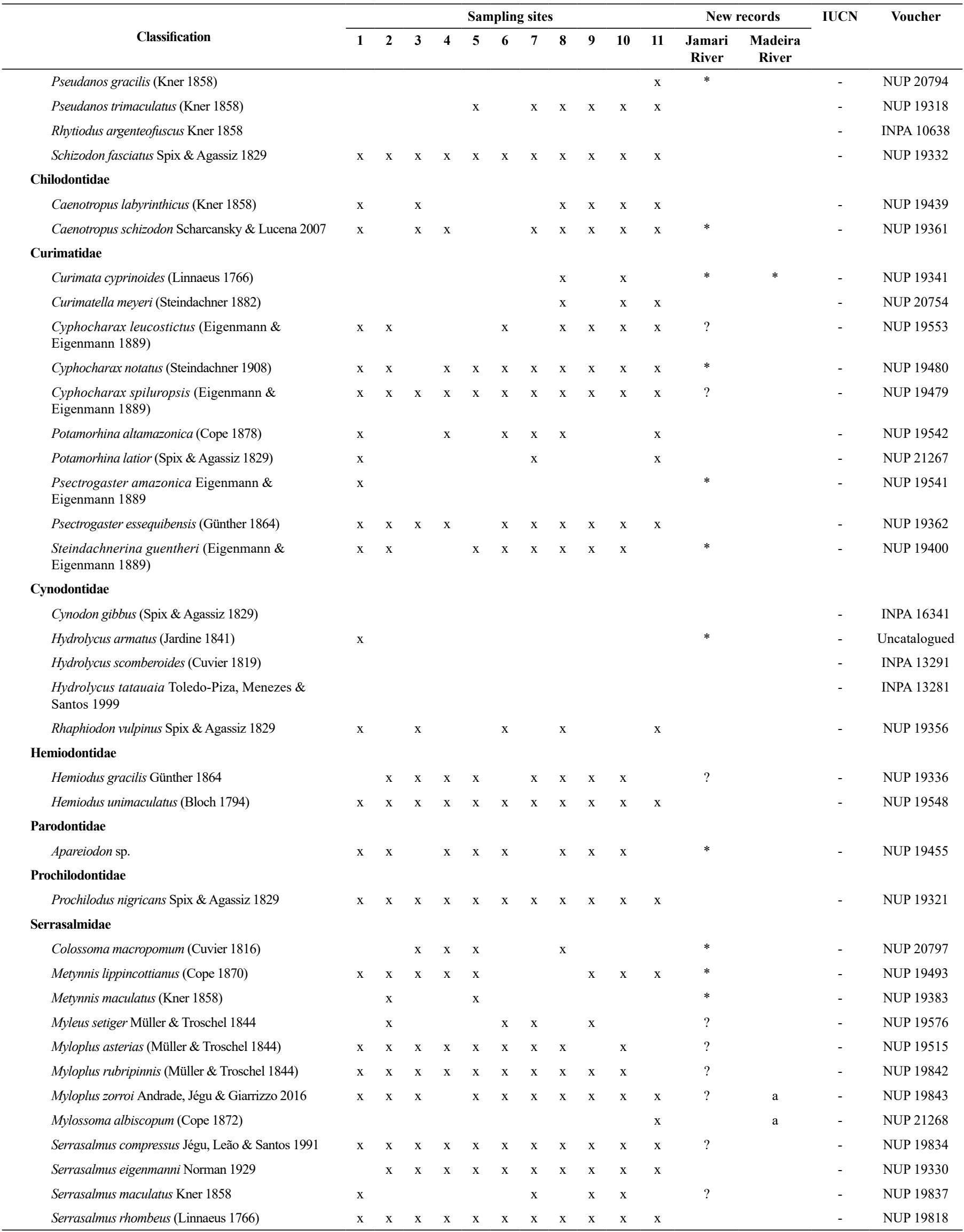


Fishes of Jamari River

Continuation Table 2.

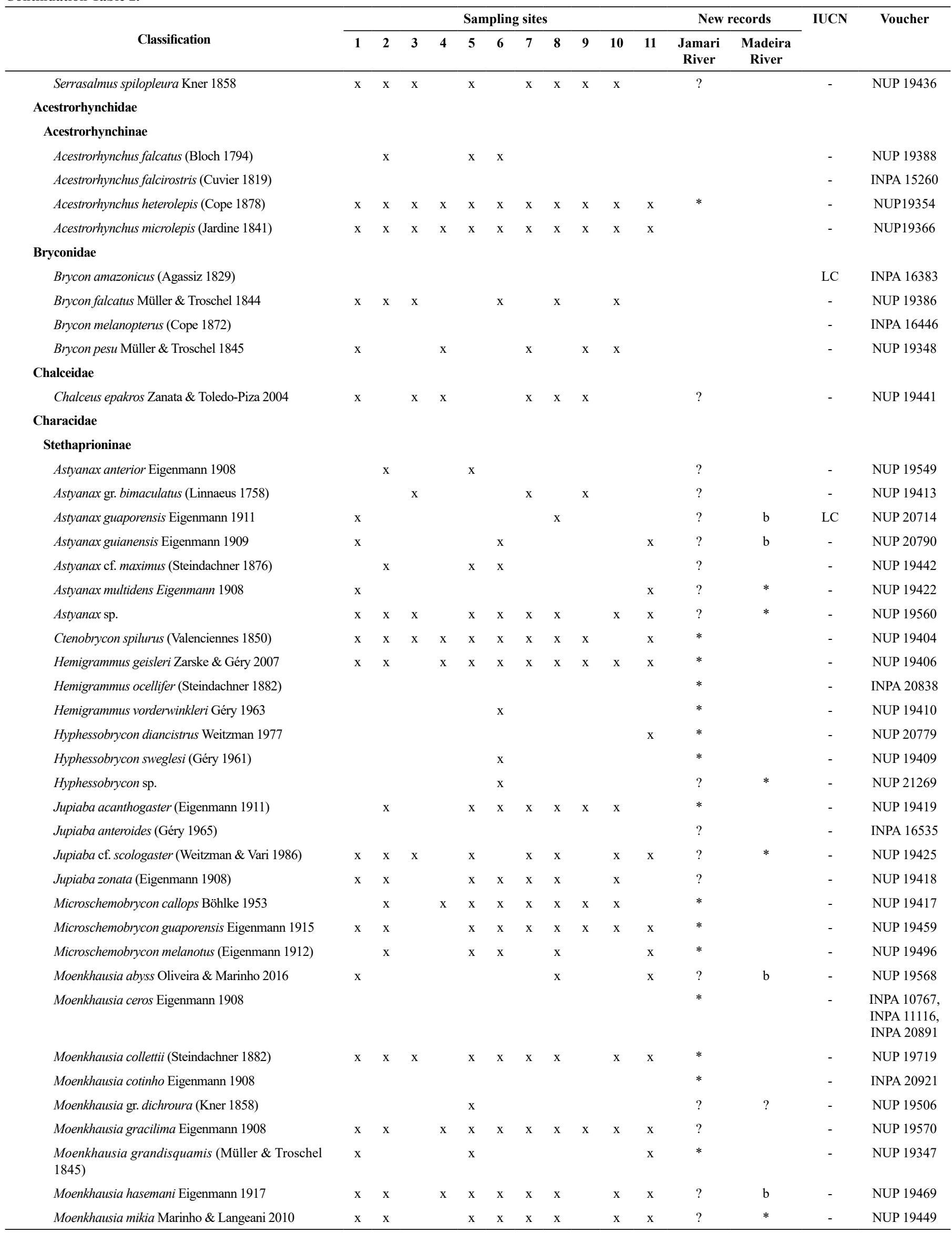




\begin{tabular}{|c|c|c|c|c|c|c|c|c|c|c|c|c|c|c|c|}
\hline \multirow[b]{2}{*}{ Classification } & \multicolumn{11}{|c|}{ Sampling sites } & \multicolumn{2}{|c|}{ New records } & \multirow[t]{2}{*}{ IUCN } & \multirow[t]{2}{*}{ Voucher } \\
\hline & 1 & 2 & 3 & 4 & 5 & 6 & 7 & 8 & 9 & 10 & 11 & $\begin{array}{l}\text { Jamari } \\
\text { River }\end{array}$ & $\begin{array}{l}\text { Madeira } \\
\text { River }\end{array}$ & & \\
\hline Moenkhausia oligolepis (Günther 1864) & & $\mathrm{x}$ & & & $\mathrm{x}$ & $\mathrm{x}$ & $\mathrm{x}$ & $\mathrm{x}$ & & $\mathrm{x}$ & & $*$ & & - & NUP 19370 \\
\hline Moenkhausia pankilopteryx Bertaco \& Lucinda 2006 & $\mathrm{x}$ & $\mathrm{x}$ & $\mathrm{x}$ & $\mathrm{x}$ & $\mathrm{x}$ & $\mathrm{x}$ & $\mathrm{x}$ & $\mathrm{x}$ & & $\mathrm{x}$ & $\mathrm{x}$ & $*$ & & - & NUP 19408 \\
\hline Moenkhausia sp. & & $\mathrm{x}$ & & & $\mathrm{x}$ & $\mathrm{x}$ & & $\mathrm{x}$ & & $\mathrm{x}$ & $\mathrm{x}$ & $*$ & $*$ & - & NUP 19720 \\
\hline Poptella compressa (Günther 1864) & $\mathrm{x}$ & $x$ & $\mathrm{x}$ & $\mathrm{x}$ & $\mathrm{x}$ & $\mathrm{x}$ & $\mathrm{x}$ & $\mathrm{x}$ & $\mathrm{x}$ & $\mathrm{x}$ & $\mathrm{x}$ & & & - & NUP 21270 \\
\hline \multicolumn{16}{|l|}{ Stevardiinae } \\
\hline Creagrutus cf. beni Eigenmann 1911 & & $\mathrm{x}$ & & & & & & & & & & $*$ & & - & NUP 20733 \\
\hline Creagrutus sp. & $\mathrm{x}$ & $\mathrm{x}$ & $\mathrm{x}$ & & $\mathrm{x}$ & $\mathrm{x}$ & $\mathrm{x}$ & $\mathrm{x}$ & $\mathrm{x}$ & $\mathrm{x}$ & $\mathrm{x}$ & * & $*$ & - & NUP 19579 \\
\hline Knodus heteresthes (Eigenmann 1908) & $\mathrm{x}$ & $\mathrm{x}$ & & $\mathrm{x}$ & $\mathrm{x}$ & $\mathrm{x}$ & $\mathrm{x}$ & $\mathrm{x}$ & $\mathrm{x}$ & $\mathrm{x}$ & $\mathrm{x}$ & $*$ & & - & NUP 19384 \\
\hline Xenurobrycon cf. pteropus Weitzman \& Fink 1985 & & $\mathrm{x}$ & & & & $\mathrm{x}$ & & & & & & * & $*$ & - & NUP 19520 \\
\hline Charax pauciradiatus (Günther 1864) & & $\mathrm{x}$ & & & $\mathrm{x}$ & $\mathrm{x}$ & $\mathrm{x}$ & & & $\mathrm{x}$ & $\mathrm{x}$ & * & a & - & NUP 19561 \\
\hline $\begin{array}{l}\text { Phenacogaster retropinnus Lucena \& Malabarba } \\
2010\end{array}$ & $\mathrm{x}$ & $\mathrm{x}$ & $\mathrm{x}$ & & $\mathrm{x}$ & $\mathrm{x}$ & $\mathrm{x}$ & $\mathrm{x}$ & $\mathrm{x}$ & $\mathrm{x}$ & $\mathrm{x}$ & * & & - & NUP 19416 \\
\hline Roeboides affinis (Günther 1868) & $\mathrm{x}$ & $\mathrm{x}$ & $\mathrm{x}$ & $\mathrm{x}$ & $\mathrm{x}$ & $\mathrm{x}$ & $\mathrm{x}$ & $\mathrm{x}$ & $\mathrm{x}$ & $\mathrm{x}$ & $\mathrm{x}$ & & & $\mathrm{LC}$ & NUP 19349 \\
\hline \multicolumn{16}{|l|}{ Cheirodontinae } \\
\hline Serrapinnus microdon (Eigenmann 1915) & & & & & & $\mathrm{x}$ & $\mathrm{x}$ & & & & & * & & - & NUP 19528 \\
\hline Serrapinnus notomelas (Eigenmann 1915) & & $\mathrm{x}$ & & & & & $\mathrm{x}$ & $\mathrm{x}$ & $\mathrm{x}$ & $\mathrm{x}$ & & $*$ & & - & NUP 19405 \\
\hline \multicolumn{16}{|l|}{ Ctenoluciidae } \\
\hline Boulengerella cuvieri (Spix \& Agassiz 1829) & $\mathrm{x}$ & $\mathrm{x}$ & $\mathrm{x}$ & $\mathrm{x}$ & $\mathrm{x}$ & $\mathrm{x}$ & $\mathrm{x}$ & $\mathrm{x}$ & $\mathrm{x}$ & $\mathrm{x}$ & $\mathrm{x}$ & & & - & NUP 19444 \\
\hline Boulengerella maculata (Valenciennes 1850) & & & & & & & & & & & & & & - & $\begin{array}{l}\text { INPA } 7335 \\
\text { INPA } 7336\end{array}$ \\
\hline \multicolumn{16}{|l|}{ Iguanodectidae } \\
\hline \multicolumn{16}{|l|}{ Pyrrhulininae } \\
\hline Nannostomus digrammus (Fowler 1913) & & & & & & & & & & & & * & & - & INPA 44369 \\
\hline \multicolumn{16}{|l|}{ Triportheidae } \\
\hline \multicolumn{16}{|l|}{ Agoniatinae } \\
\hline Agoniates halecinus Müller \& Troschel 1845 & $\mathrm{x}$ & $\mathrm{x}$ & $\mathrm{x}$ & $\mathrm{x}$ & & & & $\mathrm{x}$ & $\mathrm{x}$ & $\mathrm{x}$ & $\mathrm{x}$ & $?$ & & - & NUP 19492 \\
\hline \multicolumn{16}{|l|}{ Triportheinae } \\
\hline Triportheus angulatus (Spix \& Agassiz 1829) & $\mathrm{x}$ & & & & & & & $\mathrm{x}$ & & & $\mathrm{x}$ & & & - & NUP 19421 \\
\hline \multicolumn{16}{|l|}{ GYMNOTIFORMES } \\
\hline \multicolumn{16}{|l|}{ Gymnotidae } \\
\hline Electrophorus electricus (Linnaeus 1766) & & & & & $\mathrm{x}$ & $\mathrm{x}$ & & $\mathrm{x}$ & & $\mathrm{x}$ & & & & $\mathrm{LC}$ & NUP 19828 \\
\hline $\begin{array}{l}\text { Gymnotus carapo madeirensis Craig, Crampton \& } \\
\text { Albert } 2017\end{array}$ & & $\mathrm{x}$ & $\mathrm{x}$ & & $\mathrm{x}$ & & & $\mathrm{x}$ & $\mathrm{x}$ & & & * & & - & NUP 19535 \\
\hline $\begin{array}{l}\text { Gymnotus aff.javari Albert, Crampton \& Hagedorn } \\
2003\end{array}$ & & & & & & & & & & & & $*$ & $*$ & - & INPA 9841 \\
\hline Gymnotus gr. pantherinus (Steindachner 1908) & & & & & & & & & & & & $*$ & $*$ & - & INPA 9838 \\
\hline Gymnotus sp. & & & & & & & & & $\mathrm{x}$ & & & $*$ & $?$ & - & NUP 21273 \\
\hline Apteronotidae & & & & & & & & & & & & & & & \\
\hline Apteronotus albifrons (Linnaeus 1766) & & & $\mathrm{x}$ & & & & & & & & & $*$ & & - & NUP 19574 \\
\hline Apteronotus cf. caudimaculosus de Santana 2003 & & & & & & & & & $\mathrm{x}$ & & & $*$ & $*$ & - & Uncatalogued \\
\hline
\end{tabular}


Continuation Table 2.

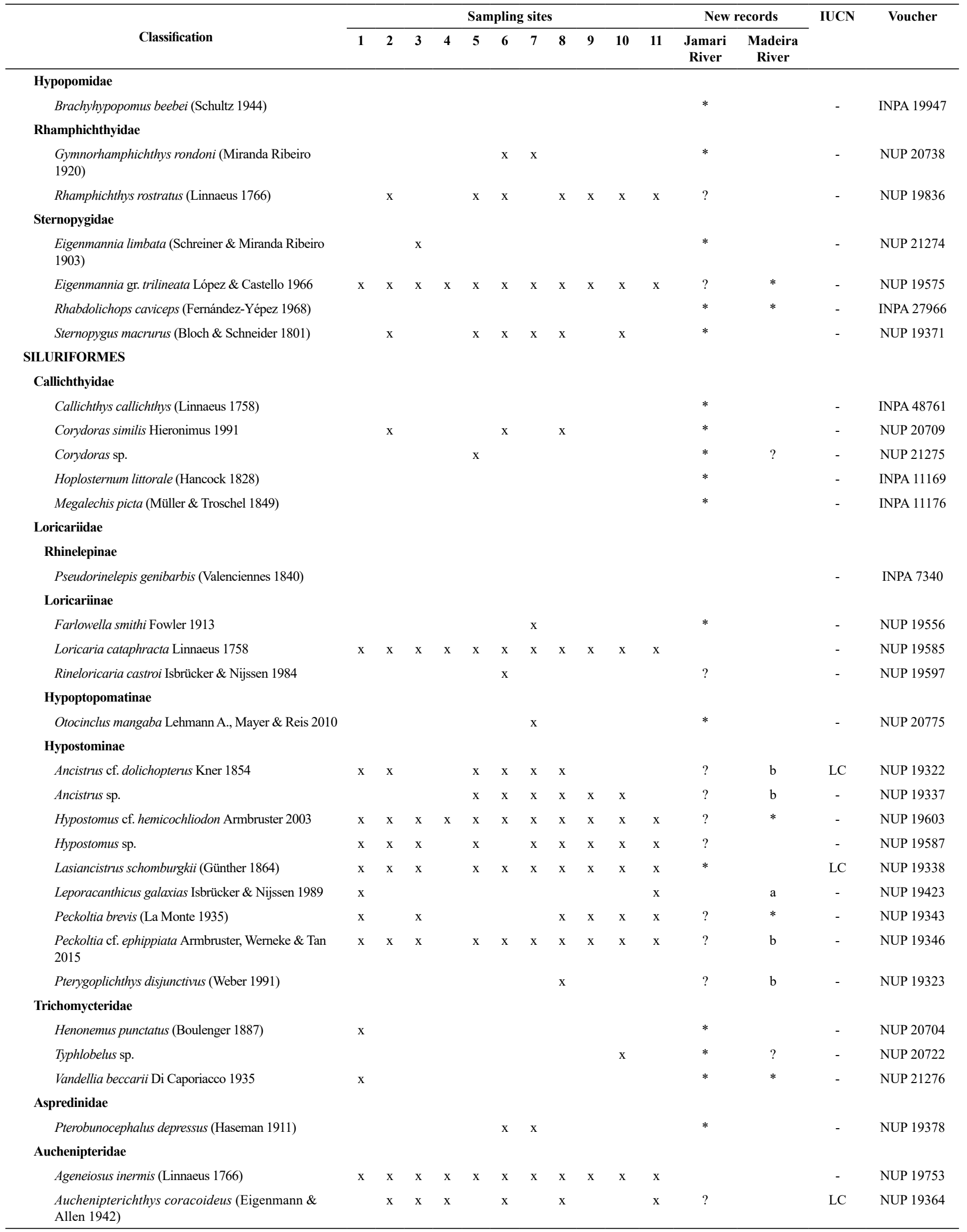




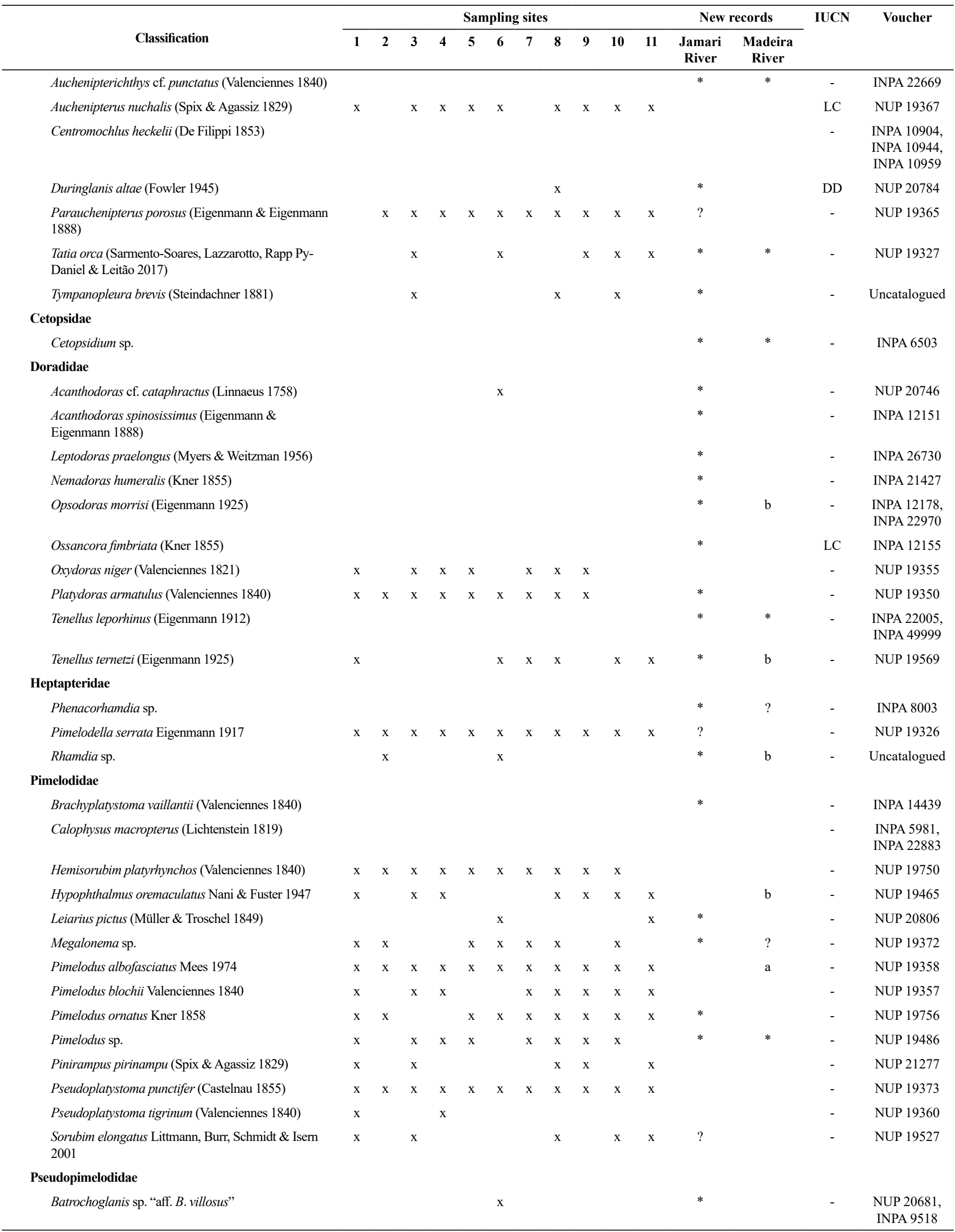


Fishes of Jamari River

Continuation Table 2.

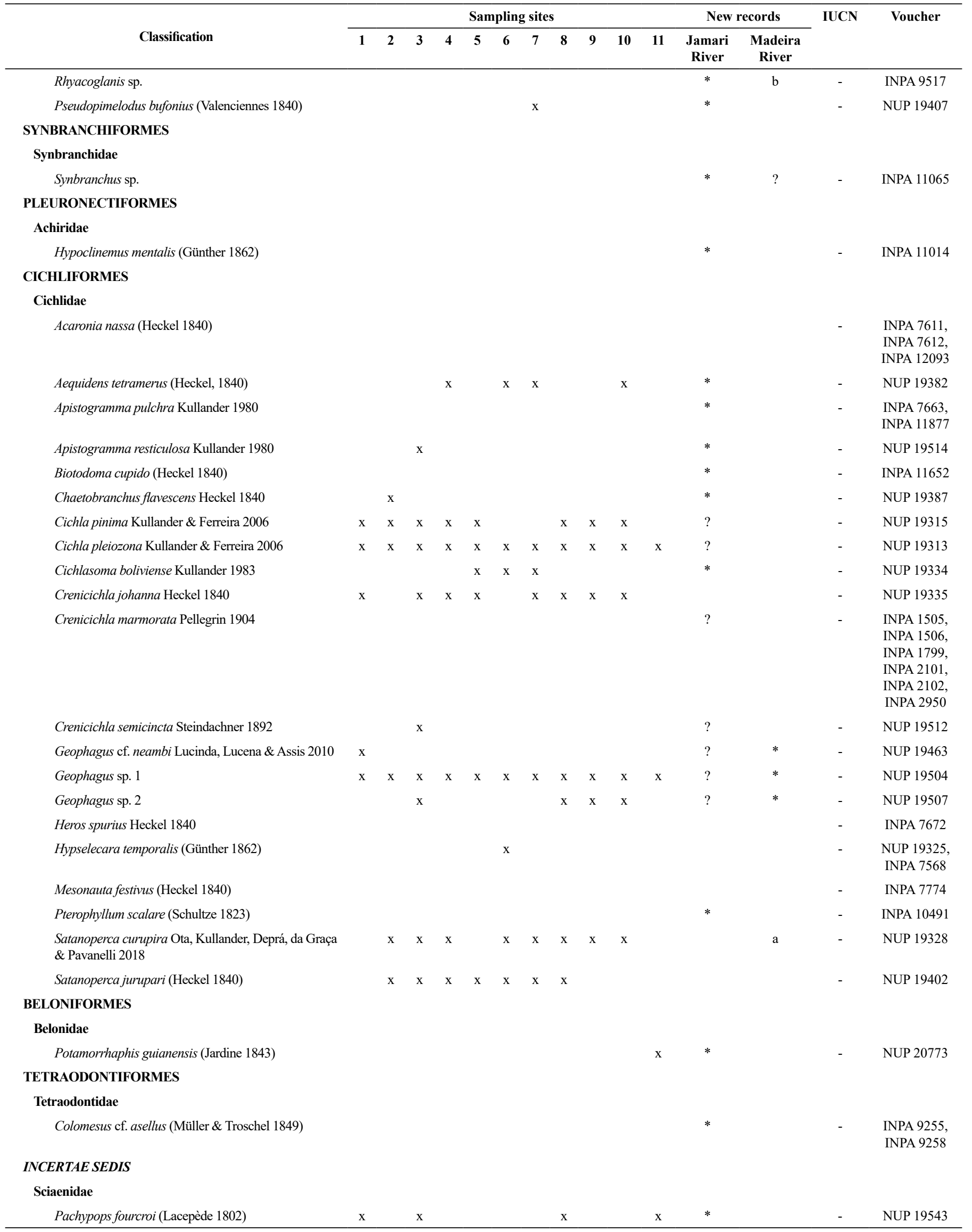




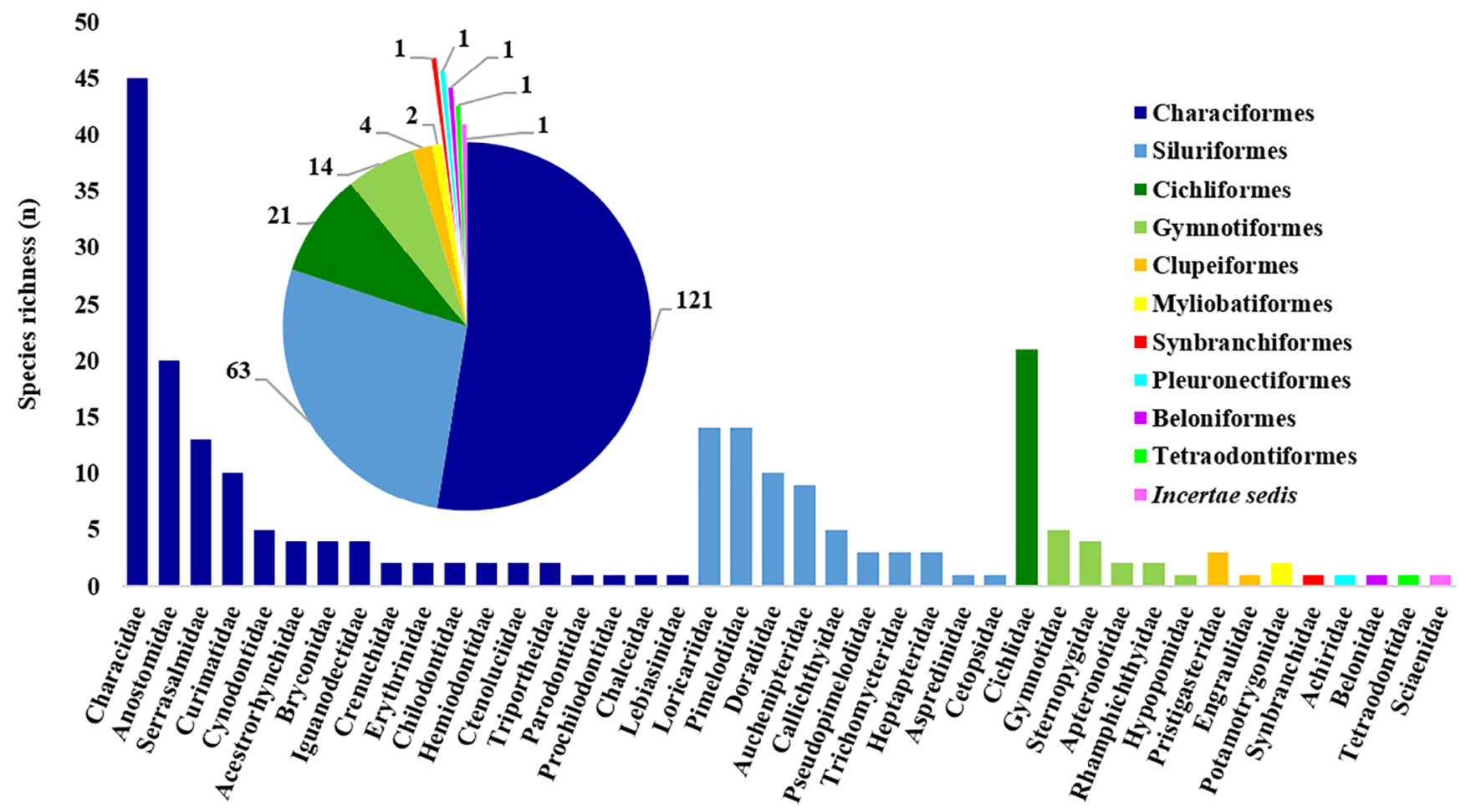

Figure 2. Distribution of number of species by families and orders.

Families

Many migratory fish species have commercial importance for the State of Rondônia, for example, branquinha-cascuda (Psectrogaster amazonica), curimatã (Prochilodus nigricans), cuiu-cuiu (Oxydoras niger), barba-chata (Pinirampus pirinampu), among others (Doria et al. 2012). However, it is common for anglers to be excluded from plans for the construction of hydroelectric dams, mitigation and compensation of social and ecological impacts (Doria et al. 2018).

The Jamari River presented high species richness (230) compared to the other tributaries of Madeira River in which studies were carried out. Among them, 48 in streams of the urban region of Rondônia (Perin 2007), 133 in the preservation area of Marmelos River (Camargo \& Giarrizzo 2007), 448 in Aripuanã River and in the middle Madeira River (Rapp Py-Daniel et al. 2007), 74 in Belmont Stream (Araújo et al. 2009), 174 in the middle Madeira River (Torrente-Vilara et al. 2011), 160 in Guariba and Roosevelt Rivers (Pedroza et al. 2012), 189 in Cuniã Lake (Queiroz et al. 2013b), 40 in streams of the Machado River basin (Casatti et al. 2013) and 74 species in Tarumã River, also belonging to the Machado River basin (Costa et al. 2017). Richness varies depending on the size and age of the reservoir and on the sampled basin, where the river basins of the Amazon region are richer when compared to others in the Neotropical region (Agostinho et al. 2016). Even though species richness increases in the initial years of the reservoir (heterotrophic phase) (Agostinho et al. 2007), it is only a reflection of the connection of different biotopes previously isolated (Agostinho et al. 2007, Agostinho et al. 2016), occurring the inverse later, whereas only tolerant species survive in the new environment (Agostinho et al. 2016). Due to the high species richness and the presence of migratory fish, it is essential to carry out continuous monitoring of the Jamari River ichthyofauna, in order to detect potential impacts generated by SHPs in the subsequent years. Also, the enhanced knowledge that would be obtained through continuous sampling would result in better decisions regarding environmental management of the basin, avoiding negative impacts on the diversity and distribution of the fish assemblage. 


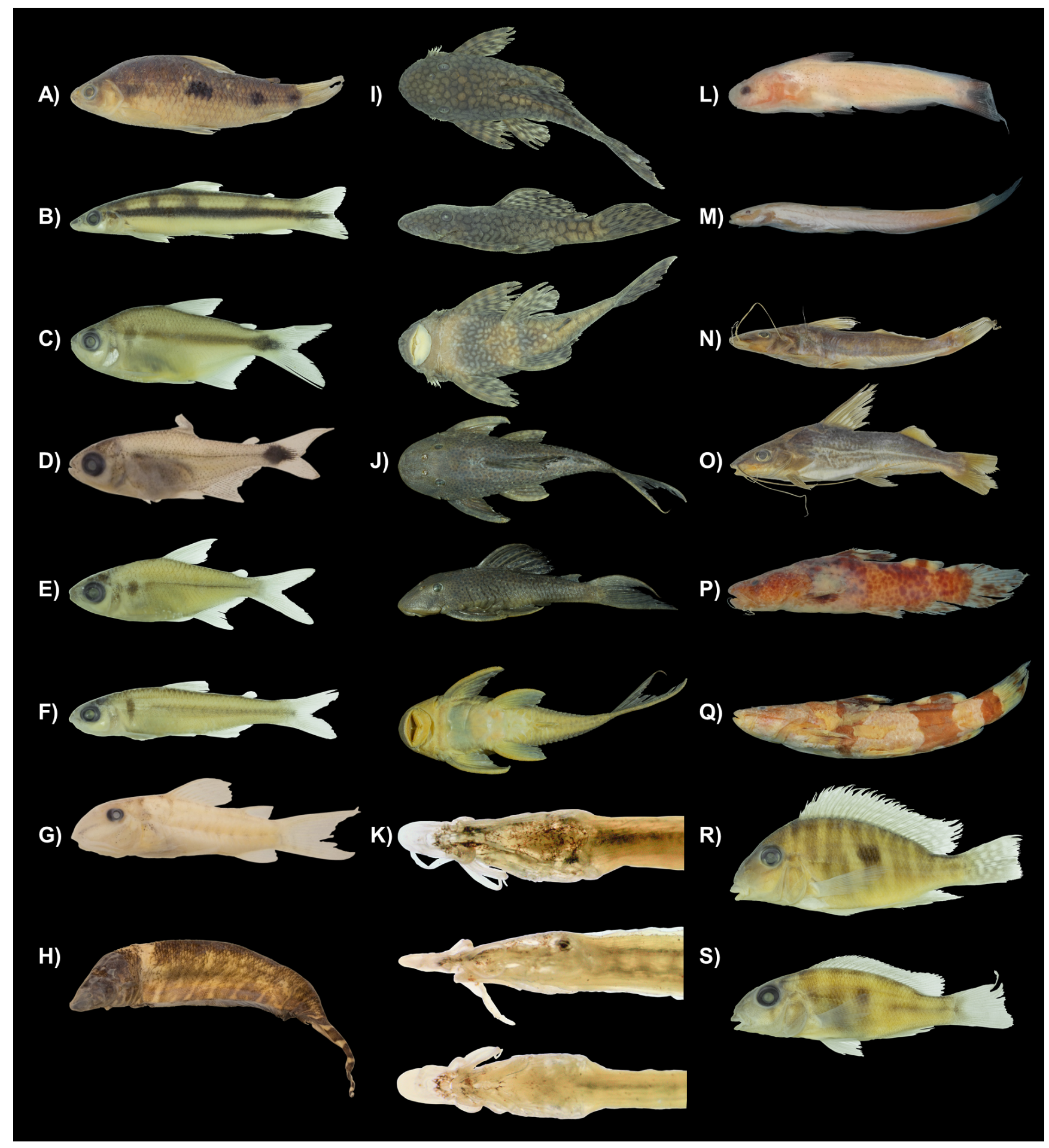

Figure 3. Putatively new species of Jamari River basin. A) Leporinus sp., NUP19345, 154.0 mm SL; B) Apareiodon sp., NUP9455, 65.4 mm SL; C) Astyanax sp., NUP19560, 50.0 mm SL; D) Hyphessobrycon sp., NUP21269, $14.0 \mathrm{~mm}$ SL; E) Moenkhausia sp., NUP19720, $24.0 \mathrm{~mm}$ SL; F) Creagrutus sp. 1, NUP19579, 33.0 mm SL; G) Corydoras sp., NUP21275, 19.0 mm SL; H) Gymnotus sp., NUP21273, 160.0 mm SL; I) Ancistrus sp. 1, NUP19337, 60.0 mm SL; J) Hypostomus sp., NUP19587, 107.0 mm SL; K) Typhlobelus sp., NUP20722, 28.0 mm SL; L) Cetopsidium sp., INPA6503, 22.3 mm SL; M) Phenacorhamdia sp., INPA8003 55.0 mm SL; N) Megalonema sp., NUP19372, 161.0 mm SL; O) sp., NUP19486, 152.0 mm SL; P) Batrochoglanis sp. "aff. B. villosus", INPA9518, 44.2 mm SL; Q) Rhyachoglanis sp., INPA9517, 58.5 mm SL; R) Geophagus sp. 1, NUP19504, 89.8 mm SL; S) Geophagus sp. 2, NUP19507, $29.6 \mathrm{~mm} \mathrm{SL}$. 


\section{Acknowledgements}

We are exceptionally grateful to Biologic Consultoria Ambiental for the data; to Carla Simone Pavanelli, curator of the ichthyological collection of the Núcleo de Pesquisas em Limnologia, Ictiologia e Aquicultura (Nupélia); to Carlos Alexandre Miranda Oliveira for the identification of Astyanax; to Luiz Peixoto and Guilherme Dutra for the identification of Eigenmannia gr. trilineata; to Isabel Soares for the identification of Moenkhausia sp.; to Luiz Tencatt for the identification of Corydoras sp.; to Rafaela Ota and Nadayca Mateussi for the identification of Serrasalmidae species; to Cárlison Oliveira for the identification of Bryconops species; to Flavio Lima for the identification of Thayeria sp. "hemiodus"; to José Birindelli for the identification of Leporinus bleheri; to James Garcia for the indetification of Poptella compressa; to Mark Sabaj for the identification of some Doradidae species; to Alessandro Bifi for the photos of Cetopsidium sp., Phenacorhamdia sp., Batrochoglanis sp. "aff. B. villosus" and Rhyacoglanis sp.; to Sandra Regina de Souza and Marli Cristina Campos for the cataloging and deposition of the specimens in the ichthyological collection of Nupélia; to Nupélia and the Pósgraduação em Ecologia de Ambientes Aquáticos Continentais (PEA) for logistical support. RCO was supported by the fellowship of the Programa de Capacitação em Taxonomia (PROTAX) of the Conselho Nacional de Desenvolvimento Científico e Tecnológico (CNPq) and the Coordenação de Aperfeiçoamento de Pessoal de Nível Superior (CAPES), GCD was supported by a scholarship from $\mathrm{CNPq}, \mathrm{CHZ}$ was supported by CNPq, and WJG was supported by personal grants from the Fundação Araucária (Seti-PR) and CNPq.

\section{Author contributions}

Rianne Caroline de Oliveira: Substantial contribution in the concept and design of the study; Contribution to data analysis and interpretation; Contribution to manuscript preparation; Contribution to critical revision, adding intellectual content.

Gabriel de Carvalho Deprá: Substantial contribution in the concept and design of the study; Contribution to data analysis and interpretation; Contribution to manuscript preparation; Contribution to critical revision, adding intellectual content.

Cláudio Henrique Zawadzki: Substantial contribution in the concept and design of the study; Contribution to data analysis and interpretation; Contribution to manuscript preparation; Contribution to critical revision, adding intellectual content.

João Carlos Barbosa da Silva: Substantial contribution in the concept and design of the study; Contribution to data collection; Contribution to data analysis and interpretation; Contribution to manuscript preparation; Contribution to critical revision, adding intellectual content.

Weferson Júnio da Graça: Substantial contribution in the concept and design of the study; Contribution to data analysis and interpretation; Contribution to manuscript preparation; Contribution to critical revision, adding intellectual content.

\section{Conflicts of interest}

The authors declare that they have no conflict of interest related to the publication of this manuscript.

\section{Ethics}

The specimens were collected with authorizations 01/2015, 02/2015 and $03 / 2015$ sent by the Secretaria de Estado do Desenvolvimento Ambiental (SEDAM) provided to João Carlos Barbosa da Silva from Biologic Consultoria Ambiental.

\section{References}

AGOSTINHO, A.A., GOMES, L.C., FERNANDES, D.R., SUZUKI, H.I. 2002. Efficiency of fish ladders for neotropical ichthyofauna. River Res. Appli. 18(3):299-306.

AGOSTINHO, A.A., GOMES, L.C., SANTOS, N.C.L., ORTEGA, J.C.G., \& PELICICE, F.M. 2016. Fish assemblages in Neotropical reservoirs: Colonization patterns, impacts and management. Fish. Res. 173:26-36.

AGOSTINHO, A.A., MARQUES, E.E., AGOSTINHO, C.S., ALMEIDA, D.A.D., OLIVEIRA, R.J. D., \& MELO, J.R.B.D. 2007. Fish ladder of Lajeado Dam: migrations on one-way routes? Neotrop. Ichthyol. 5(2):121-130.

AGOSTINHO, A.A., THOMAZ, S.M. \& GOMES, L.C. 2005. Conservação da biodiversidade em águas continentais do Brasil. Megadiversidade 1(1):70-78.

ANA, Agência Nacional de Águas. Hidroeletricidade. https://www.ana.gov.br/ usos-da-agua/hidroeletricidade (acessed 25/09/2019).

ANDRADE, M.C., JÉGU, M., \& GIARRIZZO, T. 2016. A new large species of Myloplus (Characiformes, Serrasalmidae) from the Rio Madeira basin, Brazil. ZooKeys (571):153.

ANEEL, Agência Nacional de Energia Elétrica. http://www2.aneel.gov.br/ aplicacoes/capacidadebrasil/capacidadebrasil.cfm (accessed 18/01/2019).

ARAÚJO, T.R., CELLA-RIBEIRO, A., DORIA, C.R.C. \& TORRENTEVILARA, G.T. 2009. Ichthyofauna of the stream in the Madeira River. Biota Neotrop. 9(3):21-29 http://www.biotaneotropica.org.br/v9n3/en/ abstract?article+bn00209032009 (accessed 12/02/2019).

ARMBRUSTER, J.W., WERNEKE, D.C., \& TAN, M. 2015. Three new species of saddled loricariid catfishes, and a review of Hemiancistrus, Peckoltia, and allied genera (Siluriformes). Zookeys 480:97-123.

BAIRD, R. 2010. Leveraging the fullest potential of scientific collections through digitization. Biodiversity Informatics 7(2):130-136.

BETANCUR-R, R., ARCILA, D., VARI, R.P., HUGHES, L.C., OLIVEIRA, C., SABAJ, M.H. \& ORTÍ, G. 2019. Phylogenomic incongruence, hypothesis testing, and taxonomic sampling: The monophyly of characiform fishes. Evolution 73(2):329-345.

BETANCUR-R, R., WILEY, E.O., ARRATIA, G., ACERO, A., BAILLY, N., MIYA, M., LECOINTRE, G. \& ORTÍ, G. 2017. Phylogenetic classification of bony fishes. BMC Evol. Biol. 17(1):162.

BIRINDELLI, J.L. 2014. Phylogenetic relationships of the South American Doradoidea (Ostariophysi: Siluriformes). Neotrop. Ichthyol. 12(3):451-564.

BURNS, M.D., CHATFIELD, M., BIRINDELLI, J.L. \& SIDLAUSKAS, B.L. 2017. Systematic assessment of the Leporinus desmotes species complex, with a description of two new species. Neotrop. Ichthyol. 15(2):e160166.

CAMARGO, M. \& GIARRIZZO, T. 2007. Fish, Marmelos Conservation Area (BX044), Madeira River basin, states of Amazonas and Rondônia, Brazil. Check List 3:291-296.

CASATTI, L., PÉREZ-MAYORGA, M.A., CARVALHO, F.R., BREJÃO, G.L. $\&$ da COSTA, I.D. 2013. The stream fish fauna from the rio Machado basin, Rondônia State, Brazil. Check List 9(6):1496-1504.

CASTELLO, L., \& MACEDO, M.N. 2016. Large-scale degradation of Amazonian freshwater ecosystems. Glob. Change Biol. 22(3):990-1007.

CASTELLO, L., MCGRATH, D.G., HESS, L.L., COE, M.T., LEFEBVRE, P.A., PETRY, P., MACEDO, M.N., RENÓ, V.F. \& ARANTES, C.C. 2013. The vulnerability of Amazon freshwater ecosystems. Conserv. Lett. 6(4):217-229.

COSTA, I.D., OHARA, W.M. \& ALMEIDA, M. 2017. Fishes from the Jaru Biological Reserve, Machado River drainage, Madeira River basin, Rondônia State, northern Brazil. Biota Neotrop. 17(1): e20160315 http:// dx.doi.org/10.1590/1676-0611-BN-2016-0315 (accessed 12/02/2019). 
DONASCIMIENTO, C., HERRERA-COLLAZOS, E.E., HERRERA-R, G.A., ORTEGA-LARA, A., VILLA-NAVARRO, F.A., OVIEDO, J.S.U., \& MALDONADO-OCAMPO, J.A. 2017. Checklist of the freshwater fishes of Colombia: a Darwin Core alternative to the updating problem. ZooKeys (708):25-138.

DORIA, C.R.C, ATHAYDE, S., MARQUES, E.E., LIMA, M.A.L., DUTKAGIANELLI, J., RUFFINO, M.L., KAPLAN, D., FREITAS, C.E.C. \& ISAAC, V.N. 2018. The invisibility of fisheries in the process of hydropower development across the Amazon. Ambio 47(4):453-465.

DORIA, C.R.C., RUFFINO, M.L., HIJAZI, N.C., \& CRUZ, R.L.D. 2012. A pesca comercial na bacia do rio Madeira no estado de Rondônia, Amazônia brasileira. Acta Amazon. 42(1):29-40.

FEARNSIDE, P.M. 2014. Impacts of Brazil's Madeira River dams: Unlearned lessons for hydroelectric development in Amazonia. Environ. Sci. Policy. 38:164-172.

GÉRY, J. 1999. A new anostomid species, Leporinus bleheri n. sp., from the Rio Guaporé-Iténez basin, with comments on some related species (Teleostei: Ostariophysi: Characiformes). Aqua, Journal of Ichthyology and Aquatic Biology 3(3):105-112.

IBGE, Instituto Brasileiro de Geografia e Estatística. Bacia do Rio Jamari. https:// webcache.googleusercontent.com/search?q=cache:HgoM564tuDMJ:https:// www.ibge.gov.br/home/geociencias/recursosnaturais/sistematizacao/jamari/ caracterizacao.doc $+\& c d=2 \& h l=p t-B R \& c t=c l n k \& g l=b r($ acessed 18/01/2018).

ISBRÜCKER, I.J.H. \& NIJSSEN, H. 1989. Diagnose dreier neuer Harnischwelsgattungen mit fünf neuen Arten aus Brasilien (Pisces, Siluriformes, Loricariidae). Aquarien- Terrar.-Z. 42(9):541-547.

IUCN 2019. The IUCN Red List of Threatened Species. Version 2019-2. http:// www.iucnredlist.org (acessed 25/09/2019).

LIMA, M.A.L., KAPLAN, D.A. \& DORIA, C.R.C. 2017. Hydrological controls of fisheries production in a major Amazonian tributary. Ecohydrology 10(8):e1899.

LITTMANN, M.W., AZPELICUETA, M. DE LAS M., VANEGAS-RIOS, J.A., \& LUNDBERG, J.G. 2015. Holotype-based validation, redescription and continental-scale range extension of the South American catfish species Hypophthalmus oremaculatus Nani and Fuster, 1947, with additional information on Hypophthalmus edentatus Spix and Agassiz, 1829 (Siluriformes, Pimelodidae). P. Acad. Nat. Sci. Phila. 164(1):159-177.

LOWE-MCCONNELL, R.H. 1999. Estudos ecológicos de comunidades de peixes tropicais. EDUSP, São Paulo.

LUJAN, N.K., ARMBRUSTER, J.W., LOVEJOY, N.R., \& LÓPEZFERNÁNDEZ, H. 2015. Multilocus molecular phylogeny of the suckermouth armored catfishes (Siluriformes: Loricariidae) with a focus on subfamily Hypostominae. Mol. Phylogenet. Evol. 82:269-288.

MARINHO, M.M., \& LANGEANI, F. 2016. Reconciling more than 150 years of taxonomic confusion: the true identity of Moenkhausia lepidura, with a key to the species of the M. lepidura group (Characiformes: Characidae). Zootaxa 4107(3):338-352.

MARINHO, M.M., \& OHARA, W.M. 2013. Redescription of Astyanax guaporensis Eigenmann, 1911 (Characiformes: Characidae), a small characid from the rio Madeira basin. Zootaxa 3652(4):475-484.

MARINHO, M.M., CAMELIER, P., \& BIRINDELLI, J.L. 2015. Redescription of Astyanax guianensis Eigenmann 1909 (Characiformes: Characidae), a poorly known and widespread fish from the Amazon, Orinoco and Guiana Shield drainages. Zootaxa 3931(4):568-578.

MATEUSSI, N.T., OLIVEIRA, C., \& PAVANELLI, C.S. 2018. Taxonomic revision of the Cis-Andean species of Mylossoma Eigenmann Kennedy, 1903 (Teleostei: Characiformes: Serrasalmidae). Zootaxa 4387(2):275-309.

MCEACHRAN, J.D., \& ASCHLIMAN, N. 2004. Phylogeny of Batoidea. In biology of sharks and their relatives (Carrier, J.C., Musick, J.A. \& Heithaus, M.R. eds). CRC Press, London, p.79-113.

MENEZES, N.A., \& LUCENA, C.A.S.D. 2014. A taxonomic review of the species of Charax Scopoli, 1777 (Teleostei: Characidae: Characinae) with description of a new species from the rio Negro bearing superficial neuromasts on body scales, Amazon basin, Brazil. Neotrop. Ichthyol. 12(2):193-228.
OHARA, W.M., QUEIROZ, L.J., ZUANON, J., TORRENTE-VILARA, G., VIEIRA, F.G., \& DORIA, C.R.C. 2015. Fish collection of the Universidade Federal de Rondonia: its importance to the knowledge of Amazonian fish diversity/A coleção ictiológica da Universidade Federal de Rondônia: sua importância para o conhecimento da diversidade de peixes da Amazônia. Acta Sci. Biol. Sci. 37(2):251-259.

OLIVEIRA, A.G., GOMES, L.C., LATINI, J.D., \& AGOSTINHO, A.A. 2014. Implications of using a variety of fishing strategies and sampling techniques across different biotopes to determine fish species composition and diversity. Nat. Conservação 12(2):112-117.

OLIVEIRA, G.D. \& MARINHO, M.M.F. 2016. A new species of Moenkhausia Eigenmann, 1903 (Characiformes, Characidae) from the rio Amazonas basin, Brazil. Zootaxa 4093(4):566-574.

OTA, R.R., KULlANDER, S.O., DEPRÁ, G.C., GRAÇA, W.J.D., \& PAVANELLI, C.S. 2018. Satanoperca curupira, a new cichlid species from the rio Madeira basin in Brazil (Teleostei: Cichlidae). Zootaxa 4379(1):103-112.

PEDROZA, W.S., RIBEIRO, F.R.V., TEIXEIRA, T.F., OHARA, W.M. \& RAPP PY-DANIEL, L.H. 2012. Ichthyofaunal survey of stretches of the Guariba and Rooselvelt rivers, in Guariba State Park and Guariba Extractive Reserve, Madeira River basin, Amazonas, Brazil. Check List 8(1):8-15.

PERIN, L., SHIBATTA, O.A. \& BERNARDE, P.S. 2007. Fish, Machado River basin, Cacoal urban area, state of Rondônia, Brazil. Check List 3(2): 94-97.

QUEIROZ, L.J., TORRENTE-VILARA, G., OHARA, W.M., PIRES, T.H.S., ZUANON, J. \& DORIA, C.R.C. 2013a. Peixes do rio Madeira. Dialeto Latin American Documentary, São Paulo.

QUEIROZ, L.J., TORRENTE-VILARA, G., VIEIRA, F.G., OHARA, W.M., ZUANON, J. \& DORIA, C.R.C. 2013b. Fishes of Cuniã Lake, Madeira River Basin, Brazil. Check List 9(3):540-548.

RAPP PY-DANIEL, L.H., DEUS, C.P., RIBEIRO, O.M. \& SOUSA, L.M. 2007. Peixes. In Biodiversidade do Médio Madeira: bases científicas para proposta de conservação (Rapp Py-Daniel L.H., Deus, C.P., Henriques, A.L., Pimpão D.M. \& Ribeiro O.M. eds). MMA/MCT, Manaus, p.89-125.

REIS, R.E., ALBERT, J.S., DI DARIO, F., MINCARONE, M.M., PETRY, P., \& ROCHA, L.A. 2016. Fish biodiversity and conservation in South America. J. Fish. Biol. 89(1):12-47.

SANTOS, G.M. 1996. Impactos da Hidrelétrica Samuel sobre as comunidades de peixes do rio Jamari (Rondônia, Brasil). Acta Amaz. 25(3/4):247-280.

SHIBATTA, O.A., \& VARI, R.P. 2017. A new genus of Neotropical rheophilic catfishes, with four new species (Teleostei: Siluriformes: Pseudopimelodidae). Neotrop. Ichthyol. 15(2):e160132.

SIDLAUSKAS, B.L. \& SANTOS, G.M. 2005. Pseudanos winterbottomi: a new anostomine species (Teleostei: Characiformes: Anostomidae) from Venezuela and Brazil, and comments on its phylogenetic relationships. Copeia 2005(1):109-123.

SMITH, W.S. \& PETRERE JUNIOR, M. 2008. Spatial and temporal patterns and their influence on fish community at Itupararanga Reservoir. Brasil. Rev. Biol. Trop. 56(4):2005-2020.

TORRENTE-VILARA, G., ZUANON, J., LEPRIEUR, F., OBERDORFF, T. \& TEDESCO, P.A. 2011. Effect of natural rapids and waterfalls on fish assemblage structure in the Madeira River (Amazon Basin). Ecol. Freshw. Fish. 20(4):588-597.

WEBER, C. 1991. Nouveaux taxa dans Pterygoplichthys sensu lato (Pisces, Siluriformes, Loricariidae). Rev. Suis. Zool. 98(3):637-643.

Received: $24 / 05 / 2019$

Revised: 30/10/2019

Accepted: $31 / 10 / 2019$

Published online: 13/12/2019 